\title{
Front Matter: Volume 7428
}

, "Front Matter: Volume 7428," Proc. SPIE 7428, Current Developments in Lens Design and Optical Engineering X, 742801 (17 September 2009); doi: 10.1117/12.845805

SPIE Event: SPIE Optical Engineering + Applications, 2009, San Diego, California, SPIE. United States 


\section{PROCEEDINGS OF SPIE}

\section{Current Developments in Lens Design and Optical Engineering $X$}

Pantazis Z. Mouroulis

R. Barry Johnson

Virendra N. Mahajan

Editors

3-5 August 2009

San Diego, California, United States

Sponsored and Published by

SPIE 
The papers included in this volume were part of the technical conference cited on the cover and title page. Papers were selected and subject to review by the editors and conference program committee. Some conference presentations may not be available for publication. The papers published in these proceedings reflect the work and thoughts of the authors and are published herein as submitted. The publisher is not responsible for the validity of the information or for any outcomes resulting from reliance thereon.

Please use the following format to cite material from this book:

Author(s), "Title of Paper," in Current Developments in Lens Design and Optical Engineering X, edited by Pantazis Z. Mouroulis, R. Barry Johnson, Virendra N. Mahajan, Proceedings of SPIE Vol. 7428 (SPIE, Bellingham, WA, 2009) Article CID Number.

ISSN 0277-786X

ISBN 9780819477187

Published by

SPIE

P.O. Box 10, Bellingham, Washington 98227-0010 USA

Telephone +1 3606763290 (Pacific Time) · Fax +1 3606471445

SPIE.org

Copyright (C) 2009, Society of Photo-Optical Instrumentation Engineers

Copying of material in this book for internal or personal use, or for the internal or personal use of specific clients, beyond the fair use provisions granted by the U.S. Copyright Law is authorized by SPIE subject to payment of copying fees. The Transactional Reporting Service base fee for this volume is $\$ 18.00$ per article (or portion thereof), which should be paid directly to the Copyright Clearance Center (CCC), 222 Rosewood Drive, Danvers, MA 01923. Payment may also be made electronically through CCC Online at copyright.com. Other copying for republication, resale, advertising or promotion, or any form of systematic or multiple reproduction of any material in this book is prohibited except with permission in writing from the publisher. The CCC fee code is 0277-786X/09/ $\$ 18.00$.

Printed in the United States of America.

Publication of record for individual papers is online in the SPIE Digital Library.

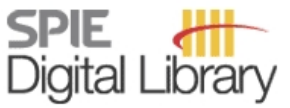

SPIEDigitalLibrary.org

Paper Numbering: Proceedings of SPIE follow an e-First publication model, with papers published first online and then in print and on CD-ROM. Papers are published as they are submitted and meet publication criteria. A unique, consistent, permanent citation identifier (CID) number is assigned to each article at the time of the first publication. Utilization of CIDs allows articles to be fully citable as soon they are published online, and connects the same identifier to all online, print, and electronic versions of the publication. SPIE uses a six-digit CID article numbering system in which:

- The first four digits correspond to the SPIE volume number.

- The last two digits indicate publication order within the volume using a Base 36 numbering system employing both numerals and letters. These two-number sets start with 00, 01, 02, 03, 04, $05,06,07,08,09,0 A, 0 B \ldots 0 Z$, followed by 10-1Z, 20-2Z, etc.

The CID number appears on each page of the manuscript. The complete citation is used on the first page, and an abbreviated version on subsequent pages. Numbers in the index correspond to the last two digits of the six-digit CID number. 


\section{Contents}

vii Conference Committee

\section{SESSION 1 PLENARY SESSION}

742802 Optical design dependence on technology development (Plenary Paper) [7428-01]

I. A. Neil, ScotOptix (Switzerland)

SESSION 2 INVITED SESSION: JOINT SESSION WITH CONFERENCE 7429

742803 The fascinating early history of optics! Archaeological optics 2009; our knowledge of the early history of lenses, mirrors, and artificial eyes! (Invited Paper) [7428-02]

J. M. Enoch, Univ. of California, Berkeley (United States)

742804 Practical design considerations for modern photographic optics (Invited Paper) [7428-03]

K. Rockwell, Consultant (United States)

742805 Display systems and registration methods for mixed reality applications (Invited Paper)

[7428-04]

D. Weng, Y. Wang, Y. Liu, J. Chen, D. Cheng, Beijing Institute of Technology (China)

\section{SESSION 3 MODELING AND OPTIMIZATION}

742806 Efficient design process for the evaluation and control of flare in opto-mechanical systems [7428-05]

M. W. Zollers, J. M. Tamkin, G. G. Gregory, Optical Research Associates (United States)

742807 Paraxial ghost image analysis [7428-06]

R. H. Abd El-Maksoud, J. M. Sasian, College of Optical Sciences, The Univ. of Arizona (United States)

742808 Finding order in the design landscape of simple optical systems [7428-07]

P. van Grol, F. Bociort, M. van Turnhout, Delft Univ. of Technology (Netherlands)

742809 Photometrically corrected holographic lens [7428-24]

J. G. Suarez-Romero, Instituto Tecnológico de Querétaro (Mexico); R. Salas-Zuñiga, Ctr. de Ingenieria y Tecnologia S.C. (Mexico)

\section{SESSION 4 OPTICAL DESIGN I}

7428 OC Design and optimization of a collimating optical system for high divergence LED light sources [7428-11]

E. Vidal, D. Otaduy, Fundación Tekniker (Spain); F. González, J. M. Saiz, F. Moreno, Univ. de

Cantabria (Spain) 
7428 OE Design method of secondary optical element for LED applications [7428-13]

Y.-Y. Chen, A. J.-W. Whang, National Taiwan Univ. of Science and Technology (Taiwan)

\section{SESSION 5 OPTICAL DESIGN II}

7428 OF Active alignment of vertebrate cone and rod photoreceptor waveguides: might this serve as a useful fiber-optics model? [7428-14]

J. M. Enoch, Univ. of California, Berkeley (United States)

7428 OG Point symmetric design approach to a wide-field wide-wavelength cat's eye retro-reflector anastigmat [7428-15]

T. W. Liepmann, Northrop Grumman Space Technology (United States)

$7428 \mathrm{OH} \quad$ Fast catadioptric optics with large field of view [7428-16]

N. Blanchard, M. Doucet, N. Desnoyers, L. Le Noc, A. Bergeron, INO (Canada)

\section{SESSION 6 OPTICAL DESIGN III}

7428 OK Thinking outside the barrel: what really matters in modern photographic lens design

[7428-19]

K. Rockwell, Consultant (United States)

\section{POSTERS SESSION}

$7428 \mathrm{ON}$ Calculation of optical forces on a dielectric bead in a geometrically aberrated trap [7428-08]

A. Carnicer, D. Garnier, S. Bosch, I. Juvells, Univ. de Barcelona (Spain)

742800 An optical switch of natural light guiding system based on cubic structure with fresnel surface [7428-23]

K.-H. Chou, Y.-Y. Chen, A. J.-W. Whang, National Taiwan Univ. of Science and Technology (Taiwan)

7428 OP Relationships between lens performance and different sensor sizes in professional photographic still SLR cameras [7428-25]

C. Mitjà, J. Escofet, F. Vega, Univ. Politècnica de Catalunya (Spain)

$74280 Q \quad$ Auto-focus imaging systems with MEMS deformable mirrors [7428-26]

M.-H. Lin, H.-T. Hsieh, National Taiwan Univ. (Taiwan); W.-Y. Hsu, Y.-C. Cheng, Instrument Technology Research Ctr. (Taiwan); C.-H. Wu, National Kaohsiung Univ. of Applied Sciences (Taiwan); G.-D. J. Su, National Taiwan Univ. (Taiwan)

7428 OR Exact analytical design method for paraxial chromatic correction in axis-symmetrical optical systems [7428-27]

B. A. Hristov, Central Lab. of Optical Storage and Processing of Information (Bulgaria)

7428 OS Exact analytical astigmatic function of aspherical surfaces [7428-28]

B. A. Hristov, Central Lab. of Optical Storage and Processing of Information (Bulgaria) 
7428 OT Optical system module having zooming function and image quality of mega pixel for a cellular phone camera [7428-29]

S. J. Park, Suncheon Cheongam College (Korea, Republic of); J. J. Lee, Kolen Co., Ltd.

(Korea, Republic of); C. S. Chung, Chonnam National Univ. (Korea, Republic of)

7428 OU Optical design of a highly segmented wide field spectrograph [7428-30]

D. Magrin, R. Ragazzoni, G. Gentile, M. Dima, J. Farinato, INAF - Osservatorio Astronomico di Padova (Italy)

Author Index 
Downloaded From: https://www.spiedigitallibrary.org/conference-proceedings-of-spie on 26 Apr 2023

Terms of Use: https://www.spiedigitallibrary.org/terms-of-use 


\title{
Conference Committee
}

\author{
Conference Chairs
}

Pantazis Z. Mouroulis, Jet Propulsion Laboratory (United States)

R. Barry Johnson, Alabama A\&M University (United States)

Virendra N. Mahajan, The Aerospace Corporation (United States)

Program Track Chair

R. John Koshel, Photon Engineering LLC (United States) and College of Optical Sciences, The University of Arizona (United States)

Program Committee

Julie Bentley, Corning Tropel Corporation (United States)

Florian Bociort, Technische Universiteit Delft (Netherlands)

Michael Chrisp, Lawrence Livermore National Laboratory (United States)

Apostolos Deslis, InPhase Technologies Inc. (United States)

Robert E. Fischer, OPTICS 1, Inc. (United States)

Alexander V. Goncharov, National University of Ireland, Galway (Ireland)

James Harvey, College of Optics and Photonics/University of Central Florida (United States)

Lakshminarayan Hazra, The Optical Society of India (India) and University of Calcutta (India)

Daniel Malacara-Doblado, Center de Investigaciones en Óptica, A.C. (Mexico)

Michael Mandina, Optimax Systems, Inc. (United States)

Laurent Mazuray, EADS Astrium (France)

Ching-Cherng Sun, National Central University (Taiwan)

Akiyoshi Suzuki, Canon Inc. (Japan)

Simon Thibault, ImmerVision (Canada) and Laval University (Canada)

Sergio Vázquez Montiel, Instituto Nacional de Astrofísica, Óptica y Electrónica (Mexico)

Yongtian Wang, Beijing Institute of Technology (China)

Andrew P. Wood, Qioptiq Ltd. (United Kingdom)

Maria J. Yzuel, Universitat Autònoma de Barcelona (Spain)

James M. Zavislan, University of Rochester (United States) 
Session Chairs

$1 \quad$ Invited Session: Joint Session with Conference 7429

R. Barry Johnson, Alabama A\&M University (United States)

2 Modeling and Optimization

Virendra N. Mahajan, The Aerospace Corporation (United States)

3 Optical Design I

Pantazis Z. Mouroulis, Jet Propulsion Laboratory (United States)

$4 \quad$ Optical Design II

Andrew P. Wood, Qioptiq Ltd. (United Kingdom)

5 Optical Design III

Florian Bociort, Technische Universiteit Delft (Netherlands) 